\title{
Lack of IgA envelope-reactive antibody producing cells in terminal ileum in early and chronic HIV-1 infection
}

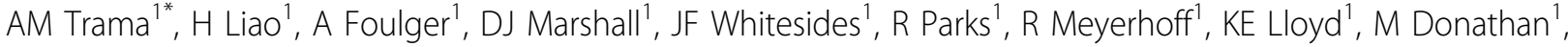 \\ J Lucas ${ }^{1}$, K Soderberg ${ }^{1}$, TB Kepler ${ }^{2}$, N Vandergrift ${ }^{1}$, N Yates $^{1}$, GD Tomaras ${ }^{1}$, MA Moody ${ }^{1}$, BF Haynes ${ }^{1}$
}

From AIDS Vaccine 2012

Boston, MA, USA. 9-12 September 2012

\section{Background}

HIV-1 vaccines must induce protective antibodies at mucosal surfaces; the role of IgA in protection remains unknown. The HIV-1 Env antibody response begins day 17 after transmission, and derives from a polyreactive memory B cell pool of gut flora-reactive IgG1 and IgA B cells. Whereas the IgG Env antibody response persists years after acute HIV-1 infection, the initial IgA response decreases over the first month. There is also selective destruction of terminal ileum germinal centers in early HIV-1 infection (EHI). To determine HIV-1 IgA responses in gut, we isolated Env-reactive antibodies from ileum from patients in EHI and chronic HIV-1 infection $(\mathrm{CHI})$.

\section{Methods}

Single plasma cells (PCs) and IgD- memory B cells were sorted from the ileum and/or blood of $7 \mathrm{EHI}$ and $3 \mathrm{CHI}$. Antibodies were isolated by PCR amplification of Ig heavy chain $\mathrm{V}(\mathrm{D}) \mathrm{J}$ and light chain $\mathrm{VJ}$ genes and characterized by ELISA and Luminex.

\section{Results}

Whereas CHI blood memory IgA $+\mathrm{B}$ cells reactive with HIV-1 envelope ranged from $0.20-0.79 \%$, only $0-0.07 \%$ of ileum IgA + B cells were Env-reactive. Of $254 \mathrm{mAbs}$ isolated from EHI ileum, only 3 (1.2\%) were HIV-1-reactive. In $\mathrm{CHI}, 9$ (5.7\%) of $158 \mathrm{mAb}$ were HIV-1 reactive. None of the HIV-1 reactive ileum antibodies were of the IgA isotype.

'Duke University, Durham, NC, USA

Full list of author information is available at the end of the article

\section{Conclusion}

HIV-1 envelope reactive IgA+ memory B cells and PCs can be found in the blood, but there is a dearth of HIV-1 reactive memory IgA $+\mathrm{B}$ cells and PCs in ileum in EHI and $\mathrm{CHI}$. Loss of IgA in plasma after acute HIV-1 infection is paralleled by the loss of $\operatorname{IgA}+\mathrm{B}$ cells in ileum, and is likely a consequence of HIV-1-induced ileum germinal center apoptosis. For vaccine design, it will be important to determine if mucosal IgA+ B cell loss is due to replicating virus or is triggered by soluble HIV-1 envelope.

\section{Author details}

'Duke University, Durham, NC, USA. 'Boston University, Boston, MA, USA.

Published: 13 September 2012

doi:10.1186/1742-4690-9-S2-P201

Cite this article as: Trama et al: Lack of IgA envelope-reactive antibody producing cells in terminal ileum in early and chronic HIV-1 infection. Retrovirology 2012 9(Suppl 2):P201.

Submit your next manuscript to BioMed Central and take full advantage of:

- Convenient online submission

- Thorough peer review

- No space constraints or color figure charges

- Immediate publication on acceptance

- Inclusion in PubMed, CAS, Scopus and Google Scholar

- Research which is freely available for redistribution

Submit your manuscript at www.biomedcentral.com/submit

\section{Ciomed Central}

(0) 2012 Trama et al; licensee BioMed Central Ltd. This is an Open Access article distributed under the terms of the Creative Commons Attribution License (http://creativecommons.org/licenses/by/2.0), which permits unrestricted use, distribution, and reproduction in any medium, provided the original work is properly cited. 